\title{
The Utilization of ICT-Based Media in Dance Learning in Schools (A Preliminary Study)
}

\author{
Fitri Daryanti ${ }^{1}$, Muhammad Jazuli ${ }^{2}$, Totok Sumaryanto $\mathrm{F}^{3}$, Hartono ${ }^{4}$ \\ (vtridaryanti@gmail.com ${ }^{1}, \underline{\text { muhjaz61@gmail.com }}$, totokunnes@yahoo.co.id ${ }^{3}$, \\ hartonosukorejo@yahoo.id ${ }^{4}$ ) \\ University of Lampung, Lampung, Indonesia ${ }^{1}$, Doctoral Student of Universitas Negeri Semarang, \\ Indonesia ${ }^{2}$, Universitas Negeri Semarang, Semarang, Indonesia ${ }^{3}$
}

\begin{abstract}
The use of ICT-based learning media in the education field is now being echoed in the education unit level. The use of technology in learning process is very effective and efficient to improve students' abilities. The purpose of this study was to design a hypothetical model of systematical ICT-based dance learning that can be used by teachers and students in creating appropriate learning activities as the orientation of $21^{\text {st }}$ century skills. Before designing the strategy, we needed teacher surveys in Lampung to configure teachers' perceptions of instructional media tas a starting point for designing strategies to follow up the $21^{\text {st }}$ century learning framework. We carried out a nonexperimental cross-sectional descriptive survey approach using a questionnaire to 10 cultural arts teachers in Lampung. Based on data analysis, it showed that all teachers were aware that in the dance learning process the impotance of digital media use. It requires applications that can help in the learning process and they must take part to overcome the challenges of the $21^{\text {st }}$ century.
\end{abstract}

Keywords: media, learning, dance, $21^{\text {st }}$ century challenge

\section{Introduction}

The advancement of technology and information increasingly shows its superiority,various technologies have penetrated almost all corners of the country. The use of ICT-based media through electronic features by the government and the private sector is to serve the needs of the community. These electronic features offer convenience in meeting the needs of government services, transportation services, health services, world education services, and life services. The use of technology in the education field is carried out by the use of various learning media in order to assist the implementation of learning process.

In the field of education, the use of technology has a positive impact. Information and communication technology (ICT) or information communication and technology (ICT) in the current era of globalization has become a fundamental need in supporting the effectiveness and quality of the education process. Education issues in Indonesia such as the quality and relevance of education, access and equity in education, geographic range, management of education, autonomy and accountability, efficiency and productivity, budget and sustainability, cannot be overcome without the help of technology. ICT-based education is a mean of interaction between management and administration in education that can be utilized by educators, education staff and students to improve the quality of learning, productivity, effectiveness and access to education. In some schools, learning materials have used ICT in the form of learning media and 
the results are very helpful for students in improving their knowledge and skills. The use of learning media in public and vocational schools or vocational schools. Here are some studies that states that in the ICT-based learning process the use of media has benefits including; can create a pleasant learning atmosphere, attract the interest of students, the interaction of learning, material that has a level of difficulty can be overcome [1], improve emotional and spiritual intelligence of students [2], increase student interest in learning [3], can stimulate the activity of participants educate and facilitate the teacher in delivering the material he teaches [4]. In addition, the availability of software, ICT training for teachers, collaboration between teachers, perceptions of self-efficacy, and teaching concepts are very influential on the use of ICT in the classroom [5].

Based on the results of the above research it can be understood that the use of technology in the field of education can basically help in the learning process in the classroom, but all depends on human resources, namely the teacher, the teacher skill and the availability of facilities and infrastructure in the school.

Indeed the purpose of learning is not only to convey information and knowledge to students, but also to foster learning attitudes and skills of students, from several studies that were carried out by previous researchers, on average discuss the benefits of learning using ICT-based media, but there is no articles discuss whether the media used can fulfill aspects of knowledge, attitudes, and skills for students and whether the media offered has been applied to the maximum extent possible in learning at school. Given that learning with the use of this technology can only be done in schools that have facilities and infrastructure, the availability of internet access, and the ability of teachers and students to operate it. Such conditions only apply to schools that have the availability of these facilities, not the same as schools that are still far from such conditions, especially schools in rural, remote and coastal areas where the majority of the population has limited access in all sectors.

Human resources and the availability of facilities and infrastructure are important in the use of ICT-based media in education. Various efforts that have been implemented and will be carried out both by the government and the community in the framework of utilizing ICT in education are very urgent and absolutely carried out in an integrated, systematic and sustainable manner. For this reason, it is necessary to conduct preliminary research on the readiness of human resources in facing the challenges in the 21 st century. Readiness of teachers in the use of ICT-based for schools in all situations and conditions, designing learning media that meet the knowledge, attitudes and skills. The purpose of this study was to design the use of ICTbased learning media for various groups of people, in formal and non-formal education and to build the character of students through digital media in facing the 21 st century challenge.

\section{Research Methodology}

The design of this study was a non-experimental cross-sectional descriptive survey approach using a questionnaire. Sample of this research was collected using purposive sampling technique, data collection using web-based survey to determine teacher perceptions and practices about ICT-based education in traditional dance learning [6]. The survey instrument consisted of 15 statements with agree, disagree and strongly agree responses. The respondents were 10 professional teachers in the Bandar Lampung City, Indonesia. They were bachelor's degree in art education. 


\section{Results And Discussion}

Now, the condition of our society is very dependent on technology, from children to adults who have been affected by advancement in technology, mobile phones and gadgets as if they are the center of their activities. Technology, information, and communication have become basic needs, everything is done easily through technological assistance, the world is in hand, with software contained in smartphone everything can be reached and can be accessed from anywhere and anytime.

The use of technology beside as a daily need is also used for education. It becomes very important in the education field especially the use in supporting activities in learning. Use of technology, information and communication in the field of education, namely as learning resources, learning aids, learning facilities, competency standards, administrative systems, decision support, and as infrastructure. [7]

As we know in our world of education today, to face the challenge in the 21 st century, the hope is that 21 st century students are independent, creative, communicative, innovative, collaborative, media and information literacy, and critical thinkers [8], and also with the teacher. Many demands that must be faced and experienced by teachers and students today. To create students as expected, teaching and learning strategies are needed and collaborating from various aspects. In addition to students the role of the teacher is very important in learning in the 21 st century, the challenge of the teacher is creating learning with the use of technology. Professional teachers are teachers who are able to think critically, creatively, collaboratively, metacognitivelly, communicatively and are able to master information technology [9]. Before designing ICT-based media, it is necessary to make survey analysis of teacher perceptions of the material and its achievement strategies, because teacher preparation equipped with ICT tools and facilities is one of the main factors in the success of technology-based teaching and learning [10]. The teacher must choose the right media [11].

\subsection{Teacher's perception of Technology-Based Teaching and Learning}

Data analysis and interpretation on teacher perception about the use of ICT-based media shown in diagram 1, it shows that most teachers were aware of the benefits of ICT-based media in teaching. The teacher realized that the use of ICTs helps teachers and students to improve the quality of teaching, the delivery of material is presented in an interesting and enjoyable manner. Teaching materials provided online were more attractive to students compared to classical methods, and for teachers can be used as a reference for designing more interesting lessons. For more details, see the following diagram.

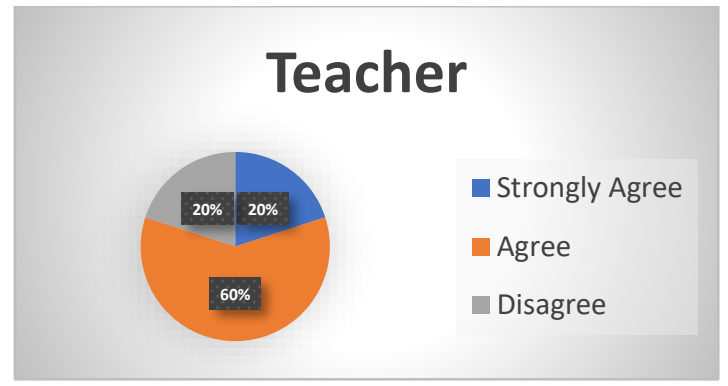

Diagram 1. Teacher Perception about The Use of ICT in teaching Dance 
Based on diagram 1, the result of a survey of teacher statements or perceptions about the use of ICT-based media, It showed that teachers who disagreed as much as $20 \%$, agree $60 \%$, and who strongly agreed as much as $20 \%$. From the diagram above showed that $20 \%$ of teachers who stated that they did not agree with the reason that the teacher was unable to operate the application, found it difficult. While teachers who agreed more because according to them the presence of media learning applications became easy, it is very helpful in conveying material that is difficult to understand, fun, and not outdated. Teachers who expressed their strong agreement with the reasons to improve their abilities, high curiosity to make the media more interesting. Although the majority of teachers stated that the use of ICT-based media is very important to be applied in learning, there are some problems with unstable internet access in network problems.

Based on the survey, it is very necessary to design ICT-based learning media as one of the learning strategies that facilitates students and teachers to learn dance material using application that is easy to understand and learn.

\subsection{Design of ICT-based dance learning media}

Learning media used in dance learning is the applications, specifications of android-based dance learning applications. As for the product specifications produced in this design, namely in the form of photos and videos of Android-based traditional dance learning related to basic motion material learning of dance. The products designed have the following specifications.

Physical Product Physical learning media in the form of a) photo / figure equipped with videos in the form of applications developed using the android studio program; b) this application is presented into an Android operating smartphone; c) the application of learning video of traditional dance can be run well on gadgets with minimum specifications of 3.0 GB RAM, 16 GB storage capacity, and android operating system; d) the design of this application is simple so that it is easy to operate with video capture in dance learning; e) blue and pink dusty layouts with the addition of audio music in the form of instruments in accordance with the local identity of the dance; f) Century Gothic font with 14 pixel title size and font type is Poor Richard with 12 pixel size; g) the language used is straightforward, communicative, and clear so that it is easier to understand the contents of the material. h) the features of games for teachers and students are useful as direct interactions between teachers and students.

Product Content The Android-based traditional dance learning video contains the descriptions of dance movements accompanied by a photo slide show, the basic video forms of dance movements include stage 1 (head, face and eye attitude), stage 2 (posture, chest and waist, stage 3 (hand gesture), and stage 4 is the attitude of the foot. The following is Figure 2. The display is the design of the traditional dance learning application. 

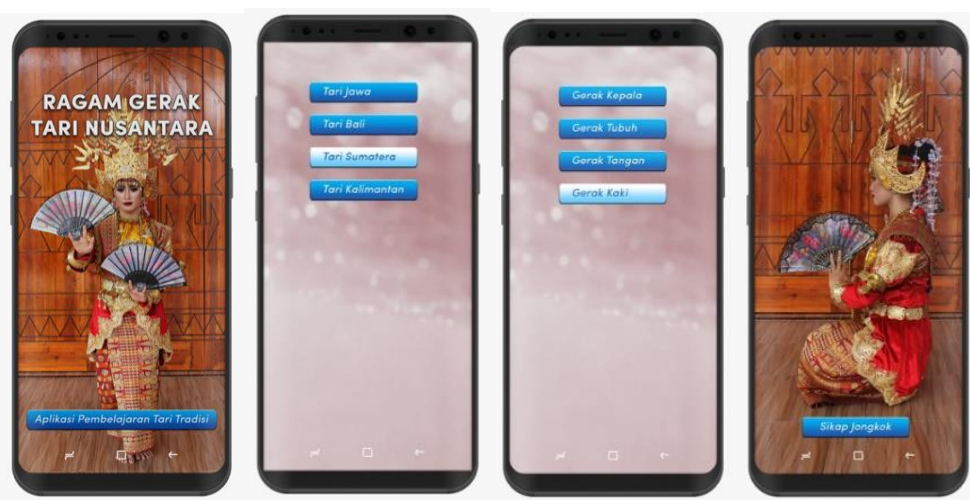

Figure 2. Design of Android-based dance learning application

In Figure 2, the appearance of an Android-based dance learning application, started with the face or cover displaying with the title of the material to be studied, then there is a button that must be pressed that will then display the next slide. There are several choices, namely dance from various regions, and when pressed one of the dances the next page will display gestures then choose which parts to learn. Simple design of Android-based traditional dance motion learning media, then it will be developed.

\section{Conclusion}

Learning about variety of traditional dance has difficulty because it must display the distinctive characteristics of each area of the archipelago starting from the head to foot, so that we need an audio visual-based learning media.

The suggestion of this study is concept of collaboration carried out by teachers and students in dance learning using digital media. To face the challenges of the 21 st century, android-based dance learning is important to be created with instructional design based on technology, information, and communication. Every collaboration made contributes and guides the behavior and character of students. This research is a preliminary, and there will be further research or further model development. 


\section{Reference}

[1] N. Made and D. Widiastuti, "Inovasi Aplikasi Media Pembelajaran Tari Bali Berbasis Android," vol. 33, no. 2, pp. 287-295, 2018.

[2] D. Anugrah et al., "The Method of Increasing Students ' Interest in ICT -Based Art and Culture Course," pp. 1-18.

[3] I. Saluza, D. Sartika, and M. Amelia, "SOSIALISASI PENGGUNAAN E-LEARNING SEBAGAI MEDIA BELAJAR SISWA SMPN 29 PALEMBANG,” vol. 1, no. 2, pp. 84-88, 2017.

[4] P. N. Tpq, "Pemanfaatan Media

[5] Pembelajaran Berbasis ICT pada Lembaga," vol. 16, no. November, pp. 215-234, 2016.

[6] J. Gil-flores and J. Rodríguez-santero, "Computers in Human Behavior Factors that explain the use of ICT in secondary-education classrooms : The role of teacher characteristics and school infrastructure," Comput. Human Behav., vol. 68, pp. 441-449, 2017.

[7] M. W. Allodi and R. Carstens, "Organisation for Economic Co-operation and Development ( OECD ) Teaching and Learning International Survey TALIS 2013 Conceptual Framework," pp. $1-60,2013$.

[8] S. Utami, R. Kamil, H. Amin, and A. Upe, "Proceeding of Community Development The Implementation of Information and Communication Technology on Learning Process in Communication Department of UHO Facing Industrial Revolution 4 . 0 [ Penerapan Teknologi Komunikasi dan Informasi Pada Pembelajaran Jurusan Ilmu Komunikasi UHO Menghadapi Revolusi Industri 4 . 0 ] Abstrak," vol. 2, pp. 344-352, 2018.

[9] U. Pendidikan, G. Singaraja, P. Seminar, and N. Quantum, "Student Centered Learning: Alternatif Pembelajaran Inovatif Abad 21 untuk Menyiapkan Guru Profesional," vol. 25, 2018.

[10] S. Ghavifekr, W. Athirah, W. Rosdy, and W. A. W. Teaching, "Teaching and Learning with Technology: Effectiveness of ICT Integration in Schools Teaching and Learning with Technology : Effectiveness of ICT Integration in Schools," 2015.

[11] R. Vanderlinde, K. Aesaert, and J. Van Braak, "Computers \& Education Institutionalised ICT use in primary education : A multilevel analysis," Comput. Educ., vol. 72, pp. 1-10, 2014

[12] A. A. Ibrahim, "Comparative Analysis between System Approach , Kemp , and ASSURE Instructional Design Models By Department of Arts and Social Sciences Education," vol. 3, no. 12, pp. 261-270, 2015. 